\title{
Pemasangan Apo Sederhana dan Penanaman Mangrove Di Wilayah Pesisir Pantai Muara Beting
}

\author{
RR. Mekar Ageng Kinasti ${ }^{1}$; Endah Lestari ${ }^{2}$; Muhammad Sofyan ${ }^{3}$; \\ Irma Wirantina Kustanrika ${ }^{4}$ \\ 1,2,3,4 Institut Teknologi PLN \\ ${ }^{1}$ mekar.ageng@itpln.ac.id
}

\begin{abstract}
Beting Beach has a very strategic position from the aspect of the environment. Abundant marine resources and endangered species such as Javan Monkey and Swamp Bird are potentials that must be preserved. Mangrove forest habitat has been converted into ponds by residents of Beting Beach. This deforestation makes the condition of Beting Beach very vulnerable and does not have a green belt from abrasion and ROB that is happening. The village of Beting is currently abandoned by many residents because the land is no longer useful. If so, the loss of this area could be a threat in the future. The purpose of this activity is to help conserve mangrove forest habitats that function as germplasm and a key to the restoration of marine ecosystems and improve the economy of citizens. The rescue effort that can be done is to replant and ensure the seedlings can grow in tidal conditions due to ROB. A total of 1000 mangrove seedlings were planted on 24 and 25 February 2020. To support the success of mangrove planting, $100 \mathrm{~m}$ of simple Wave Breakers have been installed. The combination of bamboo and a net made of a plastic called APO Semi Hybrid. The effectiveness of Mangrove ecosystems is not felt instantly, but in the next 5 to 10 years. Thus, the improvement of Beting Beach is not only the physical aspect, but also the improvement of security, land use, and the welfare of its inhabitants in the future.
\end{abstract}

Keywords: Mangrove, green belt, deforestation, abrasion, $R O B$

\begin{abstract}
ABSTRAK
Pantai Beting memiliki posisi yang sangat strategis dari aspek lingkungan. Sumber daya laut yang melimpah dan satwa langka seperti Lutung Jawa serta Burung Rawa merupakan potensi yang harus dilestarikan. Habitat hutan Mangrove telah dirubah menjadi tambak oleh penduduk Pantai Beting. Deforestasi ini menyebabkan kondisi Pantai Beting sangat rentan dan tidak memiliki green belt dari abrasi dan ROB yang sedang terjadi. Kampung Beting saat ini banyak ditinggalkan oleh penduduknya karena lahannya tidak lagi berdaya guna. Jika demikian maka, hilangnya kawasan ini dapat menjadi ancaman dikemudian hari. Tujuan dari kegiatan ini adalah untuk membantu konservasi habitat hutan mangrove yang berfungsi sebagai plasma nutfah dan kunci pengembalian ekosistem laut serta meningkatkan perekonomian warga. Upaya penyelamatan yang dapat dilakukan adalah dengan melakukan penanaman kembali dan memastikan bibit dapat tumbuh dalam kondisi pasang surut akibat ROB. Sebanyak 1000 bibit mangrove telah ditanam pada 24 dan 25 Februari 2020. Sebagai penunjang keberhasilan penanaman mangrove, sepanjang $100 \mathrm{~m}$ Alat Pemecah Ombak sederhana telah dipasang. Perpaduan dari bambu dan jaring yang terbuat dari plastic yang disebut APO Semi Hybrid. Efektivitas ekosistem Mangrove tidak dirasakan secara instan, akan tetapi pada 5 sampai 10 tahun mendatang. Dengan demikian, perbaikan Pantai Beting tidak hanya aspek fisiknya saja, akan tetapi peningkatan keamanan, daya guna lahan, dan kesejahteraan penduduknya dimasa yang akan datang.
\end{abstract}

Kata Kunci: Mangrove, green belt, deforestrasi, abrasi, ROB 


\section{PENDAHULUAN}

\subsection{Analisis Situasi}

Desa Pantai Bahagia memiliki luas sekitar $265 \mathrm{Ha}$. Daerah ini berupa pesisir yang berbatasan langsung dengan Laut Jawa di sebelah utara, bagian barat berbatasan langsung dengan Teluk Jakarta, sebelah selatan berbatasan langsung dengan daerah Babelan, sedangkan dibagian timur, daerah ini berbatasan langsung dengan Kabupaten Karawang.

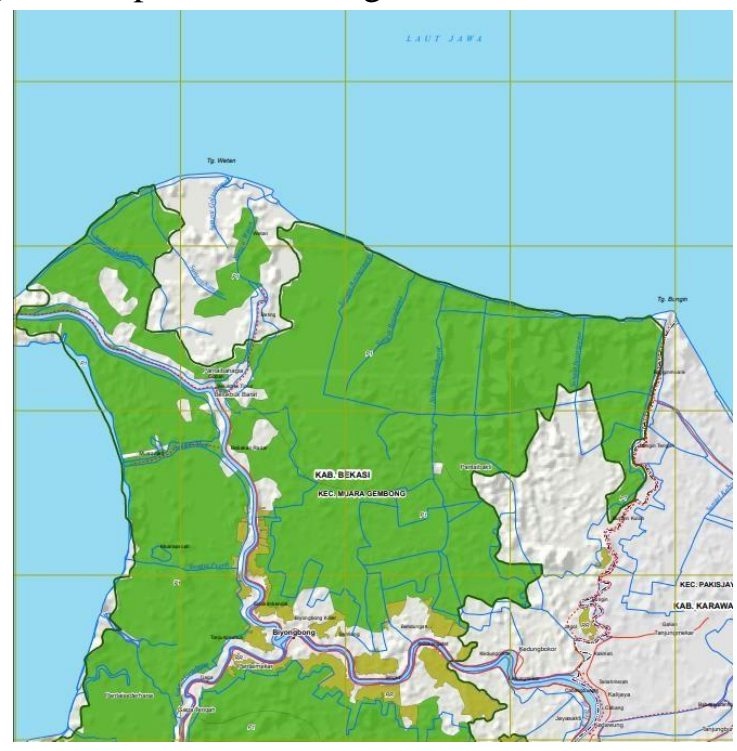

Gambar 1. Peta lokasi Program Kemitraan Masyarakat, di Kampung Beting, Desa Pantai Bahagia, Kecamatan Muara Gembong, Kabupaten Bekasi.

Morfologi di sekitar Pantai Muara Beting merupakan dataran landai dengan beda tinggi kurang lebih 0-5 meter diatas permukaan laut. Kawasan Kampung Beting ini berada dipinggir laut dan didominasi oleh area perairan. Pantai Muara Beting dapat dikatakan sebagai pesisir yang memiliki letak yang sangat strategis dari aspek lingkungan. Sebagian besar penduduk Muara Beting bermata pencaharian sebagai nelayan, menangkap ikan, kepiting dan juga udang untuk dijual ke Jakarta khususnya ke daerah Cilincing, Ancol, dan Muara Angke. Selain kaya akan sumber daya laut, desa ini juga kaya akan hewan langka, seperti lutung, burung, dan buaya rawa. Potensi terbesar yang dapat dikembangkan di Pantai Muara Beting ini adalah sebagai daerah ekowisata hutan Mangrove. Karena dimulai dari budidaya Mangrove inilah potensi sumber daya alam lainnya di daerah Pantai Muara Beting ini akan bertumbuh.

Kondisi kritisnya Kawasan hutan Mangrove di daerah ini tentunya akan mengakibatkan sejumlah dampak yang saling terkait, yaitu berubahnya keseimbangan ekosistem pantai sebagai akibat berkurangnya hutan bakau atau Mangrove [1-3], dengan demikian tentunya habitat biota maupun fauna yang mengantungkan hidup didaerah hutan Mangrove tersebut juga terancam kepunahannya. Terjadinya abrasi pantai sebagai akibat hilangnya green belt bukan lagi menjadi ancaman di derah ini, akan tetapi telah terjadi dan berlangsung hingga sekarang, 1.7 Ha lahan didesa ini tergerus abrasi. (gambar 2). 


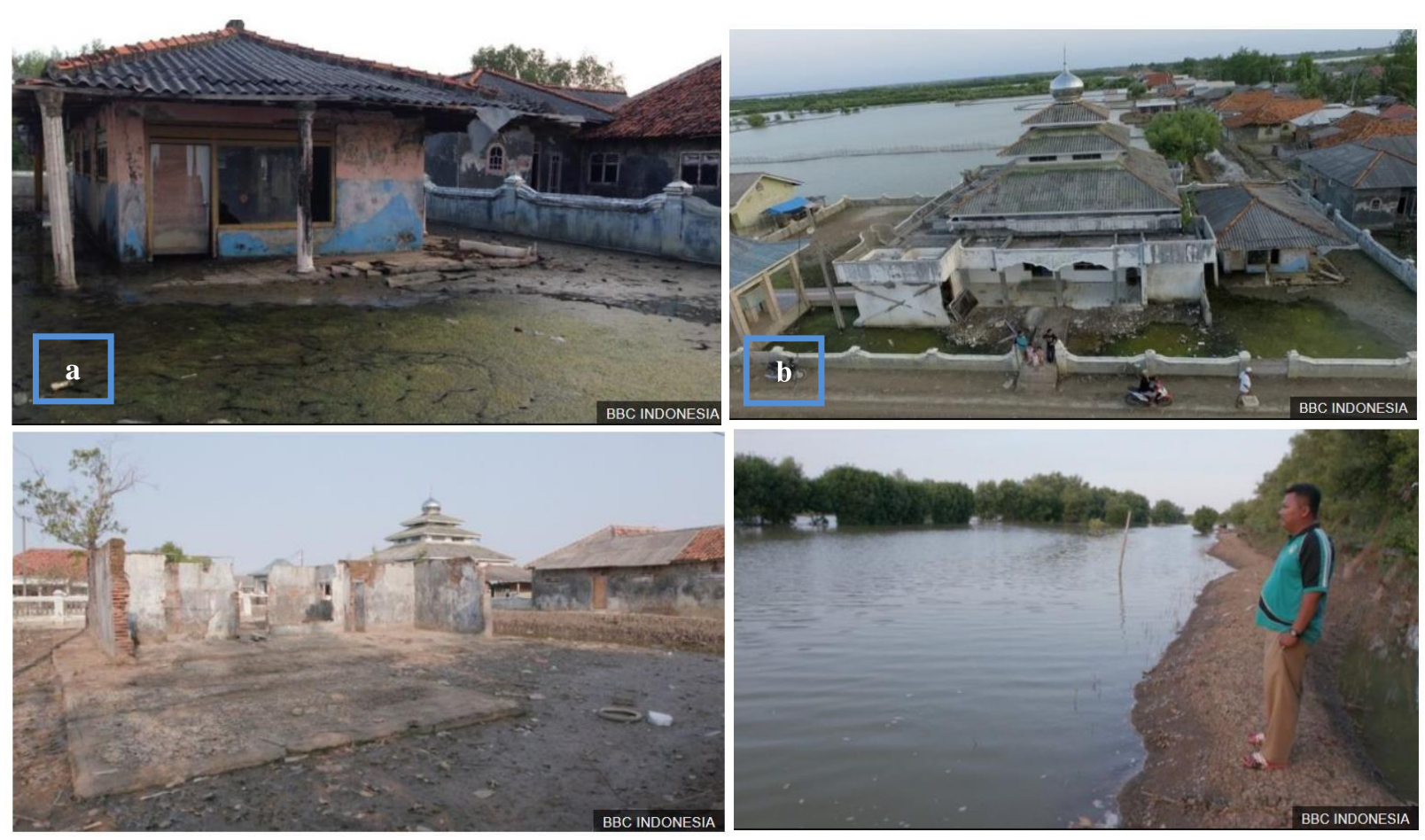

Gambar 2. Fasilitas umum yang tidak lagi dapat digunakan di Kampung Beting, dan sebagian warga memilih meninggalkan kampung ini (a,b,c) (BBC Indonesia, 16 Agustus 2017); (d) Usaha tambak yang sudah tidak produktifitas lagi dikarenakan terkena ROB (BBC Indonesia, 16 Agustus 2017).

\subsection{Tujuan Kegiatan}

Target yang ingin dicapai dalam kegiatan Pengabdian kepada Masyarakat ini adalah bibit Mangrove yang telah ditanam dapat tumbuh paling tidak $80 \%$ dari jumlah keseluruhan oleh karena itu pemasangan APO berjenis Semi Hybrid yang berbahan baku bambu dan plastik harus dilakukan guna melindungi bibit Mangrove dari arus pasang surut air laut saat terjadi ROB. Pentingnya ekosistem hutan Mangrove sebagai green belt dan upaya pemulihan habitat laut menjadikan alasan utama sebagai tolak ukur keberhasilan konservasi hutan Mangrove. Meskipun tidak instan dan memerlukan waktu yang relative lama, peningkatan pengamanan kawasan pesisir Kampung Beting dari bahaya abrasi, ROB ataupun tsunami diharapkan akan dapat tercapai. Pengamanan Kawasan ini tidak hanya dari aspek fisiknya saja akan tetapi diharapkan akan dapat diikuti dengan peningkatan daya guna kawasan, dan kesejahteraan penduduknya dimasa yang akan datang. Selanjutnya Kampung Beting akan mengalami perbaikan ketika efektifitas hutan Mangrovenya sudah mulai terasa dikemudian hari.

\subsection{Rancangan Solusi}

Metode pelaksanaan yang dipergunakan pada kegiatan ini adalah kombinasi antara metode pendekatan kelompok secara langsung dan sistem komunikasi persuasif dilapangan dengan menerapkan sistem pendidikan. Penerapan metode pendekatan kelompok secara langsung tidak mendapatkan kendala yang berarti. Warga Kampung Beting melalui Pokdarwis (Kelompok Sadar Wisata) sangat terbuka dengan masukan dan cukup teredukasi untuk pengembangan potensi dan solusi pemecahan masalah didaerahnya. Melalui kegiatan ini menambah pemahaman warga akan potensi negative geologi yang mungkin muncul, serta bagaimana upaya yang dapat kita lakukan.

Pengembangan keterampilan atau kewirausahaan telah dilakukan oleh KeMANGTEER Jakarta sebelumnya, dan warga yang tergabung dalam KEBAYA (Kelompok Bahagia Berkarya) 
telah membuat produk olahan berbahan baku Mangrove, sehinga diharapkan akan muncul minat untuk menanam bibit Mangrove dengan bertambahnya potensi ekonomis dari Mangrove. Pendekatan komunikasi lain yang kami lakukan salah satunya adalah memberikan edukasi SOP sederhana dalam mengendarai perahu motor kecil secara langsung dilapangan. Hal tersebut dikarenakan alat transportasi yang dipergunakan disana adalah perahu bagi warga yang tidak memiliki kendaraan pribadi.

\section{METODE PELAKSANAAN}

\subsection{Rencana Program Yang Disepakati Untuk Menyelesaikan Masalah}

Program yang telah disepakati bersama antara tim pelaksana Pengabdian kepada Masyarakat dengan Pokdarwis Desa Muara Gembong "Alipbata" Desa Pantai Bahagia, Kampung Beting dan dibantu oleh Kemangteer (Community Partner) dapat dilihat pada tabel berikut:

Tabel 1. Rencana program yang di sepakati untuk menyelesaikan masalah Dalam waktu 10-12 bulan

\begin{tabular}{|c|c|c|c|c|c|}
\hline \multirow[t]{2}{*}{$\mathrm{NO}$} & \multirow[t]{2}{*}{ PROGRAM YANG DISEPAKATI } & \multicolumn{3}{|c|}{$\begin{array}{l}\text { PENGELOMPOKAN } \\
\text { ASPEK }\end{array}$} & \multirow[t]{2}{*}{ KETERANGAN } \\
\hline & & EKW I & PD & PL & \\
\hline 1 & $\begin{array}{l}\text { Edukasi potensi geologi lokasi dan upaya mitigasi } \\
\text { berbasis sederhana } \\
\text { namun efisien }\end{array}$ & & $\sqrt{ }$ & & Tim P2M \\
\hline 2 & $\begin{array}{l}\text { Edukasi Mangrove, } \\
\text { pengelolaan } \\
\text { pemeliharaan, pengawasan, pendayagunaan, } \\
\text { dan pengembangan } \\
\text { fungsi) }\end{array}$ & $\checkmark$ & $\sqrt{ }$ & $\sqrt{ }$ & $\begin{array}{l}\text { Community Partner } \\
\text { Kemangteer }\end{array}$ \\
\hline 3 & Penanaman bibit Mangrove & V & & $\sqrt{ }$ & $\begin{array}{l}\text { Tim P2M, Kemangteer, } \\
\text { Pokdarwis, dan seluruh } \\
\text { peserta }\end{array}$ \\
\hline 4 & Pemasangan (APO) & $\sqrt{ }$ & & $\sqrt{ }$ & $\begin{array}{l}\text { Tim P2M, Kemangteer, } \\
\text { Pokdarwis, dan seluruh } \\
\text { peserta }\end{array}$ \\
\hline 5 & Pengawasan dan evaluasi & $\sqrt{ }$ & $\sqrt{ }$ & $\sqrt{ }$ & $\begin{array}{l}\text { Tim P2M, Kemangteer, } \\
\text { Pokdarwis }\end{array}$ \\
\hline & Keterang & $\operatorname{san}:$ & D & +2 & Ingan \\
\hline
\end{tabular}

\subsection{Partisipasi Mitra Dalam Pelaksanaan Program}

Partisipasi masing-msing mitra yang tergabung dalam kegiatan ini antara lain sebagai berikut:

1. Kelompok sadar wisata atau yang sering disebut dengan Pokdarwis Alipbata memberikan bantuan kontribusi bagi tim dengan cara mengkoordinir warga masyarakat setempat untuk mengikuti kegiatan pengabdian masyarakat ini. Pokdarwis memberikan informasi tentang kondisi lingkungan yang ada di Kampung Beting, meliputi abrasi dan habitat hutan Mangrovenya, dalam beberapa hal Pokdarwis Alipbata juga memberikan rekomendasi dalam pemilihan jenis bibit yang akan dipergunakan. Dalam kegiatan ini Pokdarwis beserta masayarakat yang akan melanjutkan pengawasan terhadap Mangrove yang kami tanam serta APOnya. 
2. Kesemat Mangrove Volunteer atau Kemangteer adalah pecinta lingkungan pemerhati habitat Mangrove, Kemangteer merupakan sukarelawan yang secara swadaya berusaha melakukan percepatan-percepatan konservasi hutan Mangrove selain dari upaya pemerintah. Kemangteer membantu kelompok P2M dalam memberikan edukasi kepada warga setempat tentang bagaimana menanam, dan merawat Mangrove, serta bagaimana mengembangkan Mangrove agar memiliki nilai ekonomis. Akan tetapi Kemangteer memiliki keterbatasan biaya dalam misinya mempercepat reklamasi Mangrove, sehingga melalui kegiatan ini diharapkan dapat mengakomodir tujuan yang sama antara Tim P2M, Kemangteer, dan Pokdarwis Alipbata.

\section{HASIL DAN PEMBAHASAN}

\subsection{Pelaksanaan Kegiatan}

Hasil dari kegiatan penanaman Mangrove dan penanaman APO ini difokuskan pada tujuan dilaksanakannya kegiatan awal. Kegiatan penanaman bibit Mangrove dan pemasangan alat pemecah ombak (APO) sepanjang 100 meter telah dilaksanakan pada hari Senin dan Selasa, tanggal 24 dan 25 Februari 2020. Kegiatan ini mendapatkan respon yang sangat baik oleh warga dan berlangsung sesuai dengan perencanaan. Bibit Mangrove yang ditanam sebanyak 1000 bibit, spesies yang dipilih adalah Sonneratia caseolaris atau sering disebut Pidada Merah. Melalui kegiatan ini tim telah membantu menyebarluaskan berbagai fungsi dari tanaman Mangrove, dan bagaimana upaya mengembalikan daya guna lahan.

Pengembalian daya guna lahan dimulai dari kembalinya ekosistem Mangrove dapat berfungsi tidak hanya pemulihan sumber daya laut yang akhirnya memperbaiki sektor ekonomi warga, akan tetapi juga sebagai investasi dimasa yang akan datang akan fungsi ekosistem Mangrove sebagai pengaman alami pesisir Pantai Beting (Green belt) dari berbagai ancaman potensi geologi negativ. Sesuai dengan target luaran kegiatan penanaman Mangrove ini menargetkan tingkat keberhasilan paling tidak $80 \%$ dari toral jumlah bibit yang ditanam. Upaya yang dilakukan untuk mencapai target tersebut adalah dengan memasang alat pemecah ombak sederhana berbahan dasar bambu dan jaring plastik (Semi Hybrid) sepanjang 100 meter dan diletakkan membatasi lokasi penanaman bibit dengan chanel yang menuju ke laut.

Melalui kegiatan PKM ini, tim menjalin Kerjasama dengan warga sekitar dalam penanaman bibit Mangrove (Pokdarwis) serta memberdayakan warga dalam pembuatan APO Semi Hybrid berbahan baku bambu dan plastik sepanjang 100 meter hingga membantu pemasangan APO dilapangan pada saat kegiatan berlangsung. Selain dengan Masyarakat, tim juga melibatkan beberapa Mahasiwa untuk dapat terlibat dalam kegiatan ini dan memperkenalkan Mahasiswa dengan KeMangteer (Volunteer Pelestarian Hutan Mangrove di Indonesia) yang aktif melaksanakan berbagai kegiatan konservasi hutan Mangrove. Dengan demikian diharapkan keterlibatan Mahasiswa dalam program pelestarian lingkungan dapat berlanjut meskipun kegiatan P2M ini telah selesai. Secara insidential tim memberikan edukasi kepada operator perahu motor maupun penumpang dalam hal prosedur sederhana mengendarai perahu motor, guna memenuhi persyaratan K3 atau mencegah terjadinya kecelakaan selama perahu berjalan, diantaranya:

1. Pastikan kondisi tubuh dalam keadaan sehat.

2. Pastikan kelengkapan APD (alat pelindung diri), pelampung dan tali penyelamat mencukupi untuk seluruh pengguna kapal

3. Pastikan kondisi perahu dalam keadaan normal dan sudah melakukan prestart check list mengenai mesin, kondisi kemudi dan lambung kapal, dan BBM cadangan 
4. Patuhi batas kapasitas penumpang

5. Kapal harus dikendarai dalam kecepatan aman

6. Pastikan saat akan memasuki perahu, perahu dalam kondisi ergonomis dan tubuh dalam keadaan aman.

7. Pastikan setelah memasuki perahu duduk dan atur keseimbangan perahu di tempat yang sudah disediakan.

8. Tidak banyak bergerak selama berada diatas perahu yang sedang berjalan

9. Pastikan perahu bersandar di tempat yang aman dan dalam keadaan ergonomis (Stabil).

Situasi pelaksanaan kegiatan dapat dilihat pada gambar 3.
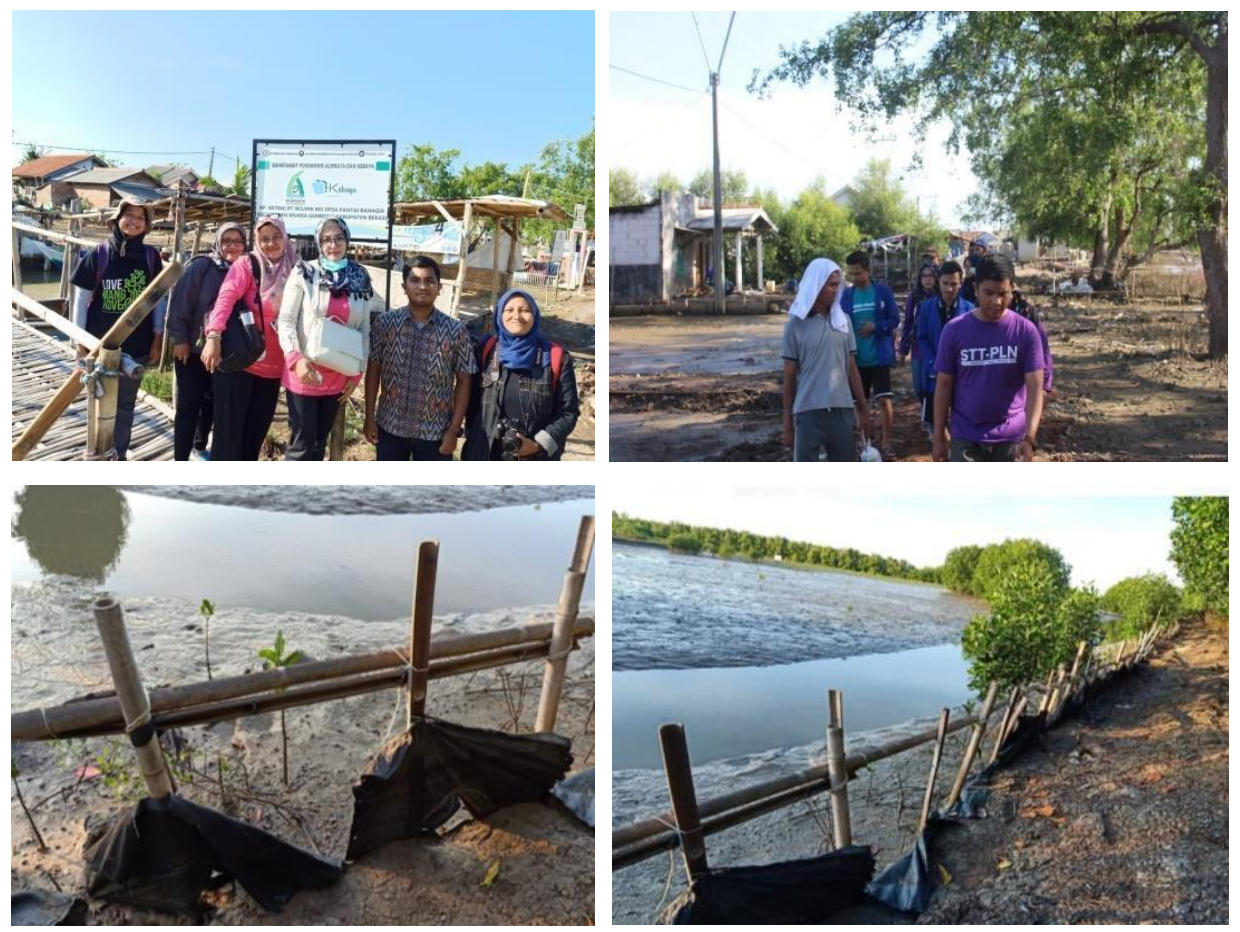

Gambar 3. Situasi pelaksanaan kegiatan

\subsection{Rencana Tahapan Selanjutnya}

Penanaman bibit Mangrove dan pemasangan pemecah ombak semi hybrid ini adalah kali pertama dilakukan oleh tim. Melihat kondisi dilapangan, Desa Pantai Bahagia ini memiliki berbagai permasalahan yang dapat dijadikan sebagai desa binaan sehingga dapat dijadikan lokasi Pengabdian kepada Masyarakat pada periode selanjutnya. Tema pengabdian yang dapat dikembang di desa ini antara lain:

1. Pengolahan air bersih, intrusi air laut yang terjadi mengakibatkan air tanah menjadi asin, sehingga jika ingin mempergunakan air tawar maka warga harus membeli air bersih.

2. Minimnya infrastruktur MCK di Desa Pantai Bahagia. Dikarenakan letaknya yang didominasi oleh perairan sehingga warga lebih memilih menggunakan sungai sebagai sarana MCK.

3. Pengembangan produksi hasil olahan Mangrove yang masih sangat manual tanpa alat bantu mesin, sehingga hasilnya kurang optimal. Selain itu pemasaran hasil olahan Mangrove juga masih sangat perlu dikembangkan

4. Rusaknya infrastruktur seperti sekolahan, rumah-rumah penduduk akibat dari ROB serta 
kurangnya sarana belajar/ Pendidikan untuk anak-anak di pesisir Pantai Beting

5. Kurangnya perahu sebagai alat transportasi bagi warga, sehingga warga disana mempergunakan perahu motor sederhana dan cenderung kurang memperhatikan aspek keselamatan.

6. Pemasangan Alat Pemecah Ombak (APO) dari beton merupakan salah satu upaya percepatan dalam mengatasi permasalahan di desa ini.

\section{KESIMPULAN}

Kesimpulan yang dapat diambil yaikni Kondisi hutan Mangrove pada Pesisir Pantai Beting sejak Tahun 2015 sampai saat ini termasuk dalam kondisi kritis, sehingga hampir tidak memiliki pelindung dari potensi geologi negative yang mungkin terjadi. Akibat kritisnya hutan Mangrove adalah terjadinya Abrasi, ROB, dan kerugian material karena rusaknya bangunan serta infrastruktur penunjang aktivitas warga. Rangkaian dampak lingkungan yang terjadi di Pesisir Pantai Beting terjadi dikarenakan perubahan fungsi lahan (hutan mengrove yang dirubah menjadi tambak) secara massif oleh warga yang dilakukan lebih dari satu dekade yang lalu.

Dampak lingkungan sebagai akibat deforestrasi tersebut tidak terjadi dalam waktu yang cepat, melainkan merupakan dampak jangka Panjang dari px`erubahan fungsi lahan yang dilakukan tanpa mempertimbangkan aspek lingkungan. Pemanfaatan fungsi lahan tidak boleh melampaui kapasitasnya, jika hal tersebut dilakukan maka, penurunan daya dukung lingkungan dapat terjadi dan memberikan dampak pada kelangsungan hidup seluruh elemen lingkungan.

Upaya yang dapat dilakukan oleh tim dalam membantu mengatasi permasalahan tersebut adalah dengan melakukan penanaman kembali bibit Mangrove sebanyak 1000 bibit guna mengembalikan ekosistem Mangrove di Pesisir Pantai Beting. Pengamanan bibit yang telah ditanam dilakukan dengan melakukan pemasangan Alat Pemecah Ombak sederhana (Semi Hybrid) sepanjang 100 meter guna melindungi bibit dari pasang surut air laut, dikarenakan ROB terjadi hampir setiap hari.

Melalui kegitan ini diharapkan perbaikan kawasan ini tidak hanya dari aspek fisiknya saja akan tetapi diharapkan akan dapat diikuti dengan peningkatan keamanan, daya guna lahan, dan kesejahteraan penduduknya dimasa yang akan datang ketika efektifitas hutan Mangrovenya sudah mulai terasa.

\section{SARAN}

Berdasarkan beberapa uraian hasil kegiatan Pengabdian kepada Masyarakat di Pesisir Pantai Beting, Salah satu hal yang sangat perlu diperhatikan selain pentingnya konservasi hutan Mangrove adalah perhatian warga terhadap keselamatan penggunaan alat transportasi berupa perahu motor yang masih sangat kurang. Pentingnya penggunaan pelampung dan melakukan pengecekan kondisi perahu sebelum perahu digunakan meskipun tanpa keluhan kerusakan tidak boleh diabaikan. Penggunaan sarana kamar mandi (MCK) sebaiknya perlu diterapkan guna meningkatkan penyehatan lingkungan yang akan memberikan dampak positif terhadap kesehatan warga sekitar. Jika dimungkinkan mendapatkan pendanaan yang lebih besar, sehingga dapat dipergunakan untuk perbaikan berbagai aspek permasalahan disana, maka manfaat pengabdian kepada masyarakat ini akan semakin dirasakan oleh warga sekitar. 


\section{UCAPAN TERIMA KASIH}

Ucapan Terima Kasih Sebesar-besarnya kami haturkan kepada Institut Teknologi PLN/YPK PLN yang mendanai kegiatan pengabdian kepada masyarakat dan Luarannya. Secara Khusus Tim PkM juga mengucapkan terima kasih sebesar besarnya kepada LPPM-IT PLN dan Fakultas Teknologi Infrastruktur Dan Kewilayahan yang telah mendukung penuh dan memfasilitasi kegiatan PkM ini.

\section{DAFTAR PUSTAKA}

[1] M. VITASARI, "Kerentanan Ekosistem Mangrove terhadap Ancaman Gelombang Ektrim/Abrasi Di Kawasan Konservasi Pulau Dua Banten,” Bioedukasi J. Pendidik. Biol., vol. 8, no. 2, p. 33, 2015, doi: 10.20961/bioedukasi-uns.v8i2.3870.

[2] A. A. Akbar, J. Sartohadi, T. S. Djohan, and S. Ritohardoyo, "Erosi Pantai, Ekosistem Hutan Bakau dan Adaptasi Masyarakat Terhadap Bencana Kerusakan Pantai Di negara Tropis (Coastal Erosion, Mangrove Ecosystems and Community Adaptation to Coastal Disasters in Tropical Countries)," J. Ilmu Lingkung., vol. 15, no. 1, p. 1, 2017, doi: 10.14710/jil.15.1.1-10.

[3] R. Novianty, S. Sastrawibawa, and D. Prihadi, "Identifikasi Kerusakan Dan Upaya Rehabilitasi Ekosistem Mangrove Di Pantai Utara Kabupaten Subang," J. Akuatika Indones., vol. 2, no. 2, p. 244613, 2011.

[4] I. Munandar, Kusumawati, "Studi analisis faktor penyebab dan penanganan abrasi pantai di wilayah pesisir aceh barat," J. Perikan. Trop., vol. 4, no. 1, pp. 47-56, 2017.

[5] K. Damaywanti, "Dampak Abrasi Pantai terhadap Lingkungan Sosial (Studi Kasus di Desa Bedono, Sayung Demak)," Pros. Semin. Nas. Pengelolaan Sumberd. Alam dan Lingkung., pp. 363-367, 2013.

[6] BNPB, 2015, Resiko Bencana Indonesia (RBI).

[7] Hilmi dkk, 2017, Indonesian Journal of Forestry Research Vol. 4, No. 2.

[8] Kemenko Kemaritiman, KLHK, dan BNPB, 2018, Sebaran Mangrove Kritis Indonesia Pada Daerah Bahaya Tsunami di Indonesia.

[9] Suryani, L.D. 2017. Rekomendasi Untuk Pelestraian Ekosistem Mangrove Dunia.

[10] Wijayanti, Sri Hapsari, 2018, Jurnal Pengabdian Masyarakat Wikrama Parahita. 